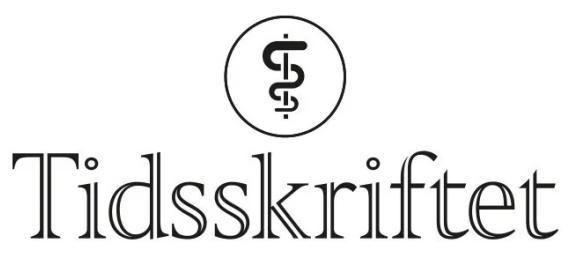

DEN NORSKE LEGEFORENING

\title{
Ensidig rødme eller ensidig blekhet?
}

\author{
MEDISINEN I BILDER
}

\section{MARTON KÖNIG}

makoni@ous-hf.no

Nevrologisk avdeling

Oslo universitetssykehus

Marton König er ph.d. og lege i spesialisering i nevrologi.

Forfatteren har fylt ut ICMJE-skjemaet og oppgir ingen interessekonflikter.

\section{JEANETTE AIMEE KOHT}

Nevrologisk avdeling

Oslo universitetssykehus

Jeanette Aimee Koht er ph.d., spesialist i nevrologi og overlege.

Forfatteren har fylt ut ICMJE-skjemaet og oppgir ingen interessekonflikter.

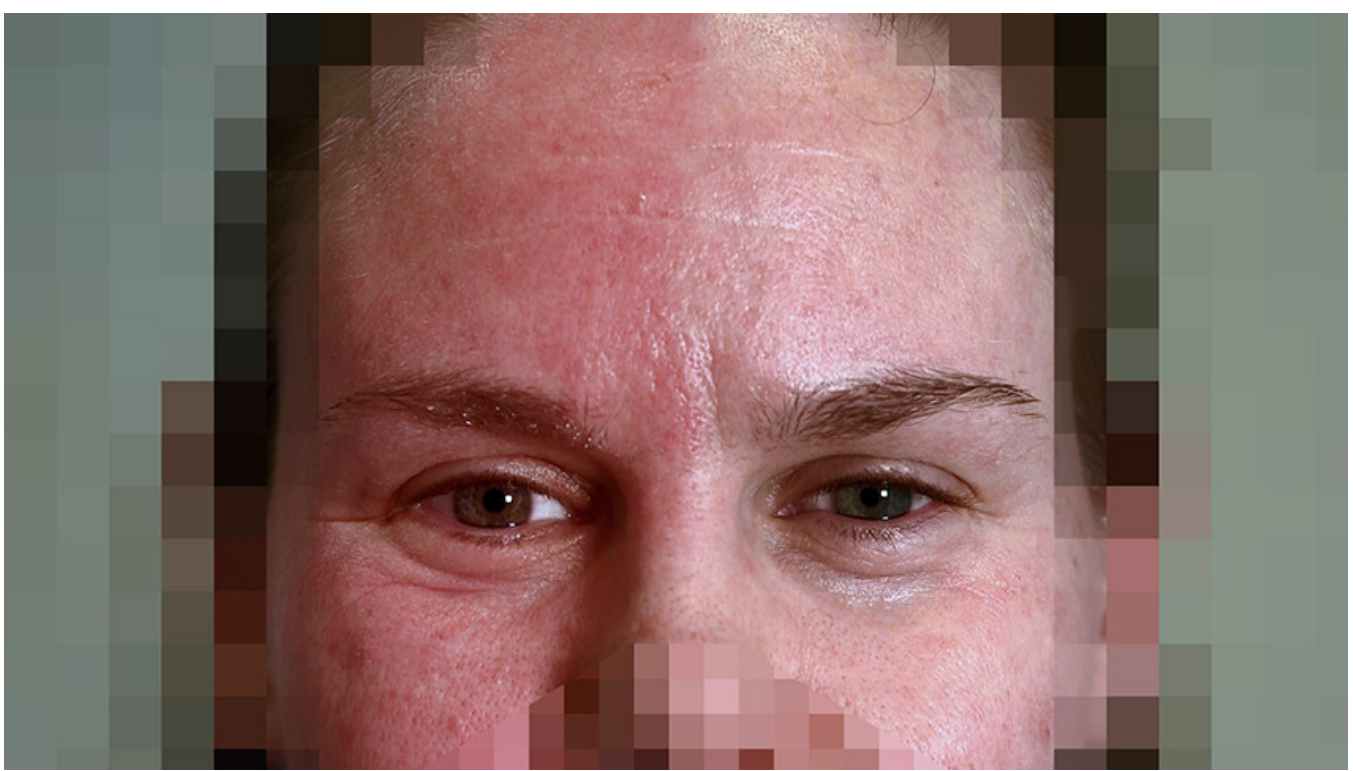

Bildet viser miose, ptose og hemifacial anhidrose med blekhet på venstre side hos en tidligere frisk kvinne i zo-årene. Bildet og videoen er tatt etter en treningstur. 
Pasienten ble henvist til nevrolog grunnet to måneders sykehistorie med ensidig ansiktsrødme. Klinisk undersøkelse avdekket lett miose, ptose, anhidrose og blekhet $\mathrm{i}$ venstre ansiktshalvdel, med skarp midtlinjegrense. Hun hadde ingen øvrige fokalnevrologiske utfall. Ved aktivitet ble hun rød på kinnet, dog kun over høyre ansiktshalvdel. Grundig utredning med gjentatte kliniske og radiologiske undersøkelser (kontrastforsterket MR av hjerne, hals, plexus brachialis og lungetoppene med angiografi) kunne ikke avdekke lesjoner i den okulosympatiske banen eller andre utløsende årsaker. Kliniske funn var forenlige med venstresidig Horners syndrom.

Den okulosympatiske banen starter sentralt med 1 . ordens nevron i hypotalamus og ender i ryggmargen (C8-Th3). Herifra fortsetter et preganglionært (2. ordens) nevron som ender i øvre cervikale ganglion på halsen, der det danner synapser med flere postganglionære (3. ordens) nevroner. Aksonene til disse ender blant annet i pupillen (1).

Årsakene til slik unilateral Horners syndrom er tallrike, både godartede og ondartede, og de kan være lokalisert en rekke steder. Hos opptil $1 / 3$ forblir årsaken ukjent (2).

Forekomsten er omtrent $2 \%$, og symptomene forblir permanente hos under halvparten av pasientene (3).

Ved affeksjon av 1. ordens nevron (oftest grunnet infarkt i laterale del av medulla oblongata) sees det vanligvis anhidrose i hodet, halsen, arm og overkropp på den affiserte siden. Den nedsatte svettesekresjonen overskygges imidlertid ofte av andre symptomer og tegn fra sentralnervesystemet. Påvirkning av preganglionære fibre (oftest av en tumor nær lungetoppen) kan gi Horners syndrom med varierende grad av ipsilateral anhidrose, mens affeksjon av 3. ordens nevroner (oftest grunnet disseksjon av arteria carotis interna) sjelden fører til anhidrose. Dette skyldes at vaso- og sudomotoriske fibre til ansiktet følger a. carotis externa. De fleste pasienter med isolert Horners syndrom har en lesjon av 3. ordens nevron.

Forskjellen i anisokorien er mer uttalt - eller mer synlig - ved dempet belysning og skyldes manglende innervasjon av musculus dilatator pupillae, mens ptosen skyldes manglende innervasjon av m. tarsalis. Avbrutt sympatisk innervasjon til ansiktets blodårer og 
svettekjertler vil kunne gi rødme på grunn av vasodilatasjon og tørrhet grunnet manglende svetteutsondring. Denervasjonen gjør imidlertid blodårene supersensitive for sirkulerende adrenalin, og derfor er vanligvis ansiktshalvdelen med den sympatiske defekten blekest, slik som i videoen.

Pasienten har gitt samtykke til at artikkelen blir publisert. Takk til Sindre Bondi for hjelp med videoopptak og bildebehandling.

\section{LITTERATUR}

1. Alstadhaug KB. Ervervet Horners syndrom. Tidsskr Nor Legeforen 2011; 131: 950-4. [PubMed] [CrossRef]

2. Patel S, Ilsen PF. Acquired Horner's syndrome: clinical review. Optometry 2003; 74: 245-56. [PubMed]

3. Moster ML. Horner's Syndrome. I: Aminoff MJ \& Daroff RB, red. Encyclopedia of the Neurological Sciences. 2. utg., Cambridge, MA: Academic Press, 2014: 610-2.

Publisert: 15. september 2021. Tidsskr Nor Legeforen. DOI: 10.4045/tidsskr.21.0319

Mottatt 16.4.2021, første revisjon innsendt 20.6.2021, godkjent 22.6.2021.

(C) Tidsskrift for Den norske legeforening 2023. Lastet ned fra tidsskriftet.no 26. april 2023. 